\title{
Tailoring surface nanoroughness of electrospun scaffolds for skeletal tissue engineering
}

Citation for published version (APA):

Chen, H., Huang, X., Zhang, M., Damanik, F., Baker, M. B., Leferink, A., Yuan, H., Truckenmuller, R., van Blitterswijk, C., \& Moroni, L. (2017). Tailoring surface nanoroughness of electrospun scaffolds for skeletal tissue engineering. Acta Biomaterialia, 59, 82-93. https://doi.org/10.1016/j.actbio.2017.07.003

Document status and date:

Published: 01/09/2017

DOI:

10.1016/j.actbio.2017.07.003

Document Version:

Publisher's PDF, also known as Version of record

Document license:

Taverne

Please check the document version of this publication:

- A submitted manuscript is the version of the article upon submission and before peer-review. There can be important differences between the submitted version and the official published version of record.

People interested in the research are advised to contact the author for the final version of the publication, or visit the DOI to the publisher's website.

- The final author version and the galley proof are versions of the publication after peer review.

- The final published version features the final layout of the paper including the volume, issue and page numbers.

Link to publication

\footnotetext{
General rights rights.

- You may freely distribute the URL identifying the publication in the public portal. please follow below link for the End User Agreement:

www.umlib.nl/taverne-license

Take down policy

If you believe that this document breaches copyright please contact us at:

repository@maastrichtuniversity.nl

providing details and we will investigate your claim.
}

Copyright and moral rights for the publications made accessible in the public portal are retained by the authors and/or other copyright owners and it is a condition of accessing publications that users recognise and abide by the legal requirements associated with these

- Users may download and print one copy of any publication from the public portal for the purpose of private study or research.

- You may not further distribute the material or use it for any profit-making activity or commercial gain

If the publication is distributed under the terms of Article $25 \mathrm{fa}$ of the Dutch Copyright Act, indicated by the "Taverne" license above, 
Full length article

\title{
Tailoring surface nanoroughness of electrospun scaffolds for skeletal tissue engineering
}

\author{
Honglin Chen ${ }^{\mathrm{a}, \mathrm{b}}$, Xiaobin Huang ${ }^{\mathrm{b}}$, Minmin Zhang ${ }^{\mathrm{c}}$, Febriyani Damanik ${ }^{\mathrm{a}}$, Matthew B. Baker ${ }^{\mathrm{a}}$, \\ Anne Leferink ${ }^{a}$, Huipin Yuan ${ }^{a}$, Roman Truckenmüller ${ }^{a}$, Clemens van Blitterswijk ${ }^{a}$, Lorenzo Moroni ${ }^{\mathrm{a}, *}$ \\ a Department of Complex Tissue Regeneration, MERLN Institute for Technology Inspired Regenerative Medicine, 6200 MD Maastricht, The Netherlands \\ ${ }^{\mathrm{b}}$ MIRA Institute for Biomedical Technology and Technical Medicine, University of Twente, 7500AE Enschede, The Netherlands \\ ${ }^{\mathrm{c}} \mathrm{MESA}+$ Research Institute, University of Twente, 7500 AE Enschede, The Netherlands
}

\section{A R T I C L E I N F O}

\section{Article history:}

Received 1 February 2017

Received in revised form 21 June 2017

Accepted 3 July 2017

Available online 6 July 2017

\section{Keywords:}

Surface roughness

Tissue engineering

Scaffold

Cell differentiation

Human mesenchymal stromal cells

\begin{abstract}
A B S T R A C T
Electrospun scaffolds provide a promising approach for tissue engineering as they mimic the physical properties of extracellular matrix. Previous studies have demonstrated that electrospun scaffolds with porous features on the surface of single fibers, enhanced cellular attachment and proliferation. Yet, little is known about the effect of such topographical cues on cellular differentiation. Here, we aimed at investigating the influence of surface roughness of electrospun scaffolds on skeletal differentiation of human mesenchymal stromal cells (hMSCs). Scanning electron microscopy (SEM) and atomic force microscopy (AFM) analysis showed that the surface nanoroughness of fibers was successfully regulated via humidity control of the electrospinning environment. Gene expression analysis revealed that a higher surface roughness (roughness average $(\mathrm{Ra})=71.0 \pm 11.0 \mathrm{~nm}$ ) supported more induction of osteogenic genes such as osteopontin (OPN), bone morphogenetic protein 2 (BMP2), and runt-related transcription factor 2 (RUNX2), while a lower surface roughness $(\mathrm{Ra}=14.3 \pm 2.5 \mathrm{~nm}$ ) demonstrated higher expression of other osteogenic genes including bone sialoprotein (BSP), collagen type I (COL1A1) and osteocalcin (OCN). Interestingly, a lower surface roughness $(\mathrm{Ra}=14.3 \pm 2.5 \mathrm{~nm})$ better supported chondrogenic gene expression of hMSCs at day 7 compared to higher surface roughness $(\mathrm{Ra}=71.0 \pm 11.0 \mathrm{~nm})$. Taken together, modulating surface roughness of 3D scaffolds appears to be a significant factor in scaffold design for the control of skeletal differentiation of hMSCs.
\end{abstract}

\section{Statement of Significance}

Tissue engineering scaffolds having specific topographical cues offer exciting possibilities for stimulating cells differentiation and growth of new tissue. Although electrospun scaffolds have been extensively investigated in tissue engineering and regenerative medicine, little is known about the influence of introducing nanoroughness on their surface for cellular differentiation. The present study provides a method to engineer electrospun scaffolds with tailoring surface nanoroughness and investigates the effect of such topographical cues on the process of human mesenchymal stromal cells differentiation into osteoblasts and chondrocytes linages. This strategy may help the design of nanostructured scaffolds for skeletal tissue engineering.

(c) 2017 Acta Materialia Inc. Published by Elsevier Ltd. All rights reserved.

\section{Introduction}

Human mesenchymal stromal cells (hMSCs) are considered as a promising candidate cell source for skeletal tissue engineering and regeneration due to their low immunogenic reaction in allogeneic

\footnotetext{
* Corresponding author.

E-mail address: l.moroni@maastrichtuniversity.nl (L. Moroni).
}

hosts and multilineage differentiation potential including the chondrogenic, adipogenic and osteogenic lineages [1-4]. Moreover, hMSCs are an easily accessible cell source [5]. In addition, hMSCs are increasingly being known to modulate injury responses through their paracrine/trophic secretion function [6,7]. Intrinsic properties of the extracellular matrix (ECM), such as chemistry and stiffness, have been demonstrated to regulate stem cell differentiation. It also has been proved that tailoring surface topography serves as one of the key roles regulating stem cell differentiation 
$[8,9]$. Dalby and his co-workers cultured hMSCs on poly(methyl methacrylate) substrate with varying ordered nanopits [10] and found that semi-ordered nanopits (120 nm diameter, $100 \mathrm{~nm}$ deep, absolute or average $300 \mathrm{~nm}$ centre-centre spacing) induced the expression of bone specific proteins in hMSCs in contrast to completely ordered or random nanopits. In the work by Nuno et al., hMSCs were cultured on polycaprolactone substrates displaying a gradient in surface roughness [8]. Specific roughness (roughness average $(\mathrm{Ra})=2.1-3.1 \mu \mathrm{m}$; root mean square roughness $(\mathrm{Rq})=71.1-48.1 \mu \mathrm{m}$ ) steered faster osteogenic commitment and stronger osteogenic expression compared to tissue culture polystyrene.

Recently, electrospun fibers have been intensively utilized as scaffolds in tissue engineering owing to their fibrous structure mimicking the physical dimensions of natural fibrous extracellular matrix [11-14]. Moreover, these fibers can be easily fabricated and modified [15]. The morphology of electrospun fibrous structure can be subdivided into the morphologies of individual fibers and fibrous meshes [16]. The modification of the morphology of individual fibers could be achieved via many approaches including varying collector temperature [17], solvent and relative humidity $[11,18]$, or by post-processing methods such as nanoimprint lithography [15], surface graft polymerization [19], physical coating or blending [20], wet chemical etching methods [21], and gas plasma [22]. Among these methods, varying the solvent and relative humidity has multiple superior advantages to other methods, since (i) it is a simple and direct process without any postelectrospinning treatment compared to nanoimprinting [15], wet chemical etching [21] and plasma [23]; (ii) it shows higher flexibility in controlling the degree of roughness than varying the collector temperature [17] and physical coating or blending [24]; (iii) it results in homogeneous treatment of each single fiber in contrast to nanoimprinting [15] and gas plasma [25] which can modify only localized surface areas of fibrous meshes. Therefore, this approach has been employed to produce electrospun scaffolds with nanoporous features on their single fibers for a wide range of applications, such as drug delivery, filtration, and tissue engineering [11,17]. Previous studies have demonstrated that the modification of the morphology of individual fibers in electrospun scaffolds can directly affect cellular response [26-30]. We previously demonstrated that hMSCs cultured on nano-porous $10 \mu \mathrm{m}$ fiber scaffolds had higher proliferation rates than hMSCs cultured on smooth $10 \mu \mathrm{m}$ fiber scaffolds [26]. In addition, these hMSC cells were found to aggregate on smooth fibers scaffolds, whereas they showed a more spread morphology on the nano-porous fiber scaffolds. Shokrgozar et al. demonstrated that nanoroughness of poly (lactic-co-glycolic acid) electrospun scaffolds could enhance nerve cell growing rate up to $50 \%$ compared to smooth electrospun scaffolds [27]. Zhang et al. revealed that the introduction of elliptical nano-pores onto the surface of aligned electrospun poly-L-lactic acid microfibers allowed for enhanced cellular response of vascular smooth muscle cells, including increased cell adhesion, proliferation, alignment, and expression of vascular matrix proteins [28]. However, all the above mentioned studies mainly focused on the influence of surface roughness of electrospun fibers on cellular adhesion and proliferation. Little knowledge on the effect of electrospun fiber surface nanoroughness on stem cell differentiation is available.

Here, we aimed at investigating the influence of electrospun fiber surface nanoroughness on the skeletal differentiation of hMSCs. The surface roughness of electrospun scaffolds was tailored through varying the humidity during electrospinning. The topographical surface was determined by scanning electron microscopy (SEM) and atomic force microscopy (AFM). The biological relevance of each surface roughness on osteogenic and chondrogenic cell differentiation was assessed in terms of cell morphology, metabolic activity, alkaline phosphatase (ALP) activity or glycosaminoglycan (GAG) production, and specific gene expression profiles.

\section{Materials and methods}

\subsection{Fabrication of scaffolds}

Poly (ethylene oxide terephthalate)/poly (butylene terephthalate) (PEOT/PBT, weight ratio of $\mathrm{PEOT} / \mathrm{PBT}=55 / 45$, molecular weight $(\mathrm{g} / \mathrm{mol})$ of starting PEG segments used in polymerization process is 300) was kindly provided by PolyVation B.V. (The Netherlands). A PEOT/PBT solution was prepared by dissolving polymer in a mixture solvent of dichloromethane/1,1,1,3,3,3-Hexa fluoro-2-propanol $(v / v=97 / 3)$ with a final concentration of $20 \%$ $(\mathrm{w} / \mathrm{v})$. The electrospinning set-up was custom-made, consisted of an environmentally controlled electrospinning chamber connected to a syringe pump, and was able to move the spinneret in the chamber to obtain a homogeneous fiber distribution during the fabrication process. The polymer solution was fed at a rate of 8 $\mathrm{mL} / \mathrm{h}$ using a syringe pump (KDS 100, KD Scientific). Applied voltage and tip-to-collector distance were $20 \mathrm{kV}$ and $15 \mathrm{~cm}$, respectively. The temperature in the electrospinning chamber was monitored during the process and kept constantly around $20^{\circ} \mathrm{C}$. The relative humidity in the spinning chamber was chosen to be around $20 \%, 50 \%$ and $70 \%$, separately.

\subsection{Fiber morphology and dimensions}

The morphology of electrospun scaffolds was observed by SEM (Philips XL30 ESEM-FEG). Prior to SEM imaging, samples were gold sputtered with a Cressington Sputter Coater 108 Auto set at $30 \mathrm{~mA}$ for $40 \mathrm{~s}$. To create cross-section images, samples were first frozen in liquid nitrogen and then cut. The average fiber diameter and fiber diameter distribution were calculated by measuring at least 30 fibers in one SEM image and five images were used for each scaffold using Adobe Photoshop CS4.

\subsection{Porosity and pore diameter of scaffolds}

Apparent density and porosity of scaffolds were calculated using the following equation [14]:

$p=\left(1-\frac{\rho^{\prime}}{\rho^{\circ}}\right) \times 100 \%$

where $p$ is the porosity of scaffold porosity, $\rho^{\prime}$ is the apparent density of scaffold and $\rho^{\circ}$ the density of polymer materials used for fabricating scaffolds.

Pore diameter of scaffolds was calculated from SEM images using ImageJ according to previous study [31]. The diameters in each of at least 30 pores within an image for a total of four images per sample were quantified.

\subsection{AFM analysis}

Surface roughness analysis was performed through AFM using Tapping Mode (PicoScan Controller 2500, Molecular Imaging, USA) with a Super Sharp TESP cantilever: $42 \mathrm{~N} / \mathrm{m}, 320 \mathrm{kHz}$, 2-5 nm ROC, No Coatings (Bruker AFM Probes) on a $1 \mu \mathrm{m}^{2}$ surface area $(n=6)$. The average roughness $(R a)$, pore depth, and surface area differences were determined using the Scanning Probe Image Processor, SPIPTM, version 4.2.2.0 software. High quality images in $3 \mathrm{D}$ of the fiber surface were visualized at randomly different surface locations to verify the reproducibility of the observed characteristics. 


\subsection{Contact angle measurements}

The wettability of scaffolds was determined by sessile drop technique using an optical contact angle device (OCA15, Dataphysics, Germany). Sessile milli-Q water drop was deposited onto sample surface with the syringe, and the drop contour was fitted by the Young-Laplace method. At least 3 different static contact angle measurements on each sample were performed.

\subsection{Nile Red staining and analysis}

The local environment of polymer surfaces was determined using a Nile Red adsorption technique. Fabricated scaffolds or spin-cast polymer films (controls) were exposed to a dilute solution $(1 \mu \mathrm{M})$ of Nile Red in milli-Q water for $1 \mathrm{~min}$. After this minute, the samples were briefly washed with fresh milli-Q water to remove excess Nile Red solution; samples were then sandwiched between a glass slide and a coverslip. Images were taken with a confocal laser excitation microscope DM6000 (Leica, Wetzlar, Germany) equipped with a DFC365FX camera. For measurement of the local environment, Nile Red $\left(\lambda_{\mathrm{ex}}=514 \mathrm{~nm}\right)$ emission was imaged over the range of $520-700 \mathrm{~nm}$ in $10 \mathrm{~nm}$ steps. Integrated intensity of the region of interest was then plotted against the average wavelength for each image, reconstituting the emission spectrum. All experiments were performed in duplicate, on two distinct samples (total of 4 measurements).

\subsection{Protein absorption on scaffolds}

Protein adsorption on electrospun scaffolds was investigated as previously described [23]. Briefly, samples were punched and placed in a 96 well plate. They were incubated in phosphate buffered saline (PBS) solution at $37{ }^{\circ} \mathrm{C}$ overnight. After removing PBS, $200 \mu \mathrm{L}$ of bovine serum albumin (BSA) solution $(2 \mathrm{mg} / \mathrm{mL}$ in PBS) was added to the wells and incubated at $37^{\circ} \mathrm{C}$ overnight. The samples were rinsed with PBS to remove any non-adherent proteins. The amount of adsorbed protein was quantified using a Bicinchoninic acid (BCA) protein assay kit (Thermo Scientific Pierce Protein Assay Kit). The absorbance was measured at $562 \mathrm{~nm}$ on a plate reader (Multiskan GO, Thermo Fisher, USA).

\subsection{Cell culture and seeding}

Human MSCs (donor No. $8001 \mathrm{~L}$ ) were isolated from bone marrow by Texas A\&M Health Science Center [32]. Briefly, bone marrow was aspirated centrifuged to separate mononuclear cells that would be considered as passage zero ( $\mathrm{PO}$ ) cells after being plated and harvested at $60-80 \%$ confluence. P0 cells were further expanded, harvested and frozen to obtain passage 1 (P1) cells. P1 cells were expanded in T-300 flasks at a density of $3 \times 10^{5}$ cells/ $\mathrm{cm}^{2}$ and cultured in basic medium (BM), comprising $\alpha$-MEM (Gibco), 10\% fetal bovine serum (Lonza), 2 mM L-glutamine (Gibco), $0.2 \mathrm{mM}$ ascorbic acid (Sigma), $100 \mathrm{U} / \mathrm{mL}$ penicillin and $100 \mathrm{mg} / \mathrm{mL}$ streptomycin (Gibco). Cells were harvested at approximately $80 \%$ confluence for further scaffold-based study.

Electrospun sheets with an average thickness of $52 \pm 11 \mu \mathrm{m}$ were punched into discs $(1 \mathrm{~cm}$ in diameter) and placed in 48 well plates. Rubber O-rings (Eriks B.V., The Netherlands) were placed on the top of electrospun discs to prevent them from floating. For sterilization, specimens were soaked in $70 \%(\mathrm{v} / \mathrm{v})$ ethanol for 15 min three times. After that, they were rinsed with sterilized PBS 1 min for three times and immersed in BM overnight before cell seeding. After removing the medium from scaffolds, hMSCs were seeded on each scaffold at a density of $1.5 \times 10^{4}$ cells $/ \mathrm{cm}^{2}$ in $80 \mu \mathrm{L}$ BM. Cell-scaffold constructs were incubated for $4 \mathrm{~h}$ to allow cell attachment, and topped up to $1 \mathrm{~mL}$ of $\mathrm{BM}$, osteogenic differentiation medium (OM) (BM plus $10^{-6} \mathrm{M}$ dexamethasone), or chondrogenic differentiation medium (CM). CM was composed of DMEM (Gibco), 1\% ITS premix (Micronic BV), $50 \mu \mathrm{g} / \mathrm{mL}$ ascorbic acid (Sigma-Aldrich), 100 units/mL penicillin (Life Technologies), $100 \mu \mathrm{g} / \mathrm{mL}$ streptomycin (Life technologies), $100 \mathrm{nM}$ dexamethasone (Sigma-Aldrich), $40 \mu \mathrm{g} / \mathrm{mL}$ proline (Sigma-Aldrich), $100 \mu \mathrm{g} /$ $\mathrm{mL}$ sodium pyruvate (Life Technologies), $0.01 \mu \mathrm{g} / \mathrm{mL}$ TGF- $\beta 3$ (R\&D systems). The cell-scaffold constructs were cultured in an incubator with $5 \% \mathrm{CO}_{2}$ humid atmosphere at $37{ }^{\circ} \mathrm{C}$ up to 21 days. Culture medium was refreshed every two days.

\subsection{Fluorescence microscopy}

On day 3, samples were fixed with $4 \%(\mathrm{v} / \mathrm{v})$ paraformaldehyde/ PBS for $2 \mathrm{~h}$ at room temperature (RT) and then washed three times with PBS. Cells were permeabilized using 0.5\% Triton X-100 solution for $10 \mathrm{~min}$ at RT and washed three times with PBS again. 1\% BSA in PBS solution was added to block non-specific binding overnight at $4{ }^{\circ} \mathrm{C}$. After withdrawing the BSA solution, phalloidin (Alexa Fluor 647, Invitrogen; Excitation/Emission: 650/668 nm) with a dilution (1:40) in 1\% BSA/PBS was applied for $30 \mathrm{~min}$ at RT in the dark and washed three times with PBS. Afterwards, $0.1 \mu \mathrm{g} / \mathrm{mL}$ DAPI/PBS was applied for $5 \mathrm{~min}$ at RT in the dark. Images were acquired using an inverted fluorescent microscope (Nikon Eclipse Ti-S).

\subsection{Metabolic activity}

PrestoBlue $^{\mathrm{TM}}$ assay was used to assess cellular metabolism. Briefly, cell culture media in sample plates were replaced with media containing 10\% (v/v) PrestoBlue ${ }^{\mathrm{TM}}$ reagent (Life technologies) and the sample plates were wrapped with aluminum foil to avoid light, followed by incubating at $37^{\circ} \mathrm{C}$ for $1 \mathrm{~h}$. Fluorescence was measured at $590 \mathrm{~nm}$ with a PerkinElmer Victor 31420 multilabel plate reader. Cell metabolic activity was analyzed on day 7 and day 21. Afterwards, samples were kept in $-80^{\circ} \mathrm{C}$ for further ALP or GAG analysis.

\subsection{Quantification of DNA}

The total amount of DNA per scaffold was quantified as described in a previous study [33]. Briefly, samples were washed twice with PBS and then processed to digest for $16 \mathrm{~h}$ in a Tris/EDTA buffer composed of $1 \mathrm{mg} / \mathrm{mL}$ proteinase $\mathrm{K}, 18.5 \mu \mathrm{g} / \mathrm{mL}$ iodoacetamine (Sigma-Aldrich) and $1 \mu \mathrm{g} / \mathrm{mL}$ Pepstatin A (SigmaAldrich). The lysate was divided into two parts. One part was used for ALP or GAG assay and the left part was used for DNA assay. For DNA quantification, the lysate was added to a buffer containing RNase $(\times 1000)$, component B (part of the DNA quantification kit) and NaCl-EDTA buffer. Subsequently, quantification of total amount of DNA per scaffold was performed using the CyQuant ${ }^{\circledR}$ DNA assay (Life Technologies) according to manufacturer's protocol. The signal was measured on a spectrophotometer (Victor 3 1420, PerkinElmer, USA) at an excitation wavelength of $480 \mathrm{~nm}$ and emission wavelength of $520 \mathrm{~nm}$.

\subsection{Alkaline phosphatase (ALP) activity assay}

The ALP activity was assessed as in a previous study [23]. Briefly, cell lysate mentioned in the DNA assay paragraph was digested for $1 \mathrm{~h}$ at room temperature with a buffer at a $\mathrm{pH}$ of 7.8 composed of $0.1 \mathrm{M} \mathrm{KH}_{2} \mathrm{PO}_{4}, 0.1 \mathrm{M} \mathrm{K}_{2} \mathrm{HPO}_{4}$ and $0.1 \%$ Triton X-100. After that, a CDP-star ${ }^{\circledR}$ solution (Roche Life Science) was added and samples were incubated for $15 \mathrm{~min}$ at room temperature. The signal was analyzed using a Victor 31420 plate reader 
(PerkinElmer, USA). The value of ALP activity per scaffold was normalized to its corresponding DNA quantity.

\subsection{Glycosaminoglycan (GAG) assay}

Cell lysates mentioned in the DNA assay paragraph were pipetted in duplicate to 96-well plates. After addition of a dimethylmethylene blue dye (DMMB, Sigma-Aldrich) solution comprising $10 \mathrm{mM}$ hydrochloric acid, $3.04 \mathrm{~g} / \mathrm{L}$ of glycine, and $2.37 \mathrm{~g} / \mathrm{L}$ of $\mathrm{NaCl}$, the plates were measured at an absorbance of $525 \mathrm{~nm}$ using a micro plate reader (Multiskan GO, Thermo Fisher, USA). The amount of GAG was calculated using a standard of chondroitin sulfate (Sigma-Aldrich).

\subsection{RNA isolation and gene expression}

Total RNA per scaffold was isolated following the protocol based on a previous study [34]. Briefly, samples were rinsed with PBS three times prior to adding $1 \mathrm{~mL}$ TRIzol reagent (Invitrogen). Subsequently, $200 \mu \mathrm{L}$ of chloroform was added to all samples, mixed vigorously, and centrifuged at $1200 \mathrm{~g}$ for $15 \mathrm{~min}$ at $4{ }^{\circ} \mathrm{C}$. The aqueous phase containing RNA was transferred to filter columns provided by the NucleoSpinRNAII ISOLATION kit (Bioke) and the purification process was performed according to the manufacturer's protocol. The concentration and purity of total RNA were determined by using an ND 1000 Nanodrop (Life Technologies, USA). One $\mu \mathrm{g}$ of total RNA was used for first strand cDNA synthesis using iScript (Bio-Rad, Veenendaal, The Netherlands) following the manufacturer's protocol. Quantitative polymerase chain reaction (qPCR) was carried out on a BioRad CFX96 real time PCR machine using SYBR-green supermix (Bio-Rad) and the primers were listed in Table 1. The Cycling conditions for running qPCR were as following: initial denaturation was at $95^{\circ} \mathrm{C}$ for $10 \mathrm{~min}$, followed by 40 cycles of $15 \mathrm{~s}$ at $95^{\circ} \mathrm{C}$ and $1 \mathrm{~min}$ at $60^{\circ} \mathrm{C}$. Relative expression of RNA was normalized to housekeeping gene B2 M, and fold changes were calculated using the $2^{-\Delta \Delta C \mathrm{~T}}$ method, where $\Delta \Delta C_{\mathrm{T}}=\left(C_{\mathrm{T}, \text { Target }}-C_{\mathrm{T}, \mathrm{B} 2 \mathrm{M}}\right)_{\text {time } x}-\left(C_{\mathrm{T} \text {,Target }}-C_{\mathrm{T}, \mathrm{B} 2 \mathrm{M}}\right)_{\text {time } 0}$.

\subsection{Statistical analysis}

Statistical analysis was determined using GraphPad Prism 5.01 (GraphPad software, San Diego, USA) for windows. Two-way analysis of variance (ANOVA), followed by a Tukey's post hoc test was performed to compare gene expression, metabolic activity, GAG production and ALP activity. One-way ANOVA with Bonferroni's multiple comparison tests were used to compare the surface roughness. A p value lower than 0.05 was considered statistically significant.

Table 1

Sequences of primers used in real time RT-PCR.

\begin{tabular}{lll}
\hline Gene & Forward primer $5^{\prime}$ to $3^{\prime}$ & Reverse primer $5^{\prime}$ to $3^{\prime}$ \\
\hline B2M & ACAAAGTCACATGGTTCACA & GACTTGTCTTTCAGCAAGGA \\
ALP & ACAAGCACTCCACTTCATC & TTCAGCTCGTACTGCATGTC \\
RUNX2 & TGGTTACTGTCATGGCGGGTA & TCTCAGATCGTTGAACCTTGCTA \\
COL1A1 & GAGGGCCAAGACGAAGACATC & CAGATCACGTCATCGCACAAC \\
BSP & CCCCACCTTTTGGGAAAACCA & TCCCCGTTCTCACTTTCATAGAT \\
COL2A1 & CGTCCAGATGACCTTCCTACG & TGAGCAGGGCCTTCTTGAG \\
SOX9 & TGGGCAAGCTCTGGAGACTTC & ATCCGGGTGGTCCTTCTTGTG \\
ACAN & AGGCAGCGTGATCCTTACC & GGCCTCTCCAGTCTCATTCTC \\
ALCAM & ACGATGAGGCAGACGAGATAAGT & CAGCAAGGAGGAGACCAACAAC \\
\hline
\end{tabular}

\section{Results and discussion}

\subsection{Characterization of electrospun scaffolds}

The relative humidity showed a remarkable effect on the surface roughness of electrospun scaffolds. At a relative humidity of $20 \%$, the morphology of fibers was smooth (Fig. 1A and 1D). Increasing the relative humidity to $50 \%$ resulted in apparent changes in surface morphology of fibers. Fig. 1E shows that surface features or pores become evident. When the humidity increased from $50 \%$ to $70 \%$, the pore depth increased as well as the pore size leaving little space between adjacent pores. The mechanism of pore formation is complex. Breath figure and phase separation models have been applied to elucidate the mechanism of pore formation in electrospun fibers $[11,35,36]$. If the breath figure model plays a major role in determining pore formation, the pore size would primarily be a function of humidity [11]. However, in the present study, humidity does not show an apparent influence on pore formation when the ratio of HFIP in the solvent system was above $5 \%$ (data not shown). A similar phenomenon was demonstrated by Ping et al. who electrospun polystyrene fibers using dimethylformamide (DMF) and tetrahydrofuran (THF) [35]. They did not find a different change in fiber morphology due to variation of humidity when THF was replaced with DMF. On the basis of this finding, phase separation is the most probable mechanism for pore formation in the present study. There are two main phase separation mechanisms to produce porous fibers: vapor-induced and thermal-induced phase separation models [11,18]. The nonsolvent phase (water vapor in the atmosphere of electrospinning chamber) penetrates into the polymer solution of jet causing a vapor-induced phase separation. In the meantime the liquid jet cools down considerably due to the evaporation of volatile solvent leading to a thermal-induced phase separation. Both phase separation models cause formation of a solvent-rich phase and polymerrich phase. The solvent-rich phase will cause formation of pores on the fiber surface, whereas the polymer-rich phase will eventually evolve into a solid matrix. The cross-section images (Fig. 1G-I) indicated that all fibers had solid interiors wrapped by an increasingly porous outer layer with increasing humidity. Overall, the solvent is one of the key elements in terms of tailoring surface nanoroughness via modulating humidity during electrospinning.

In addition, to investigate the effect of humidity on the topology of pores, AFM analysis was performed. Three dimensional representations of surface topography for the electrospun fibers illustrate the differences in surface roughness between fibers by varying the humidity (Fig. 2A). These results were in agreement with the SEM data mentioned above. The quantification results of surface roughness parameters including Ra, pore depth and surface area difference were presented in Fig. 2B. A significant difference in surface roughness was observed between fibers fabricated at different humidity. Changing humidity from $20 \%$ to $70 \%$ corresponded to increasing Ra from $14.3 \pm 2.5 \mathrm{~nm}$ to $71.0 \pm 11.0 \mathrm{~nm}$, surface area from $3.1 \pm 0.8 \mathrm{~nm}$ to $63.3 \pm 6.2 \mathrm{~nm}$ and pores depth from $27.2 \pm 4.7 \mathrm{~nm}$ to $230.5 \pm 31.9 \mathrm{~nm}$. Altogether, increasing of relative humidity resulted in an increase of roughness, depth, and surface area of pores on the surface of electrospun fibers. Similar findings were also reported by previous studies where a more porous morphology appeared on the surface of polystyrene fibers as electrospinning was performed in a higher-humidity environment $[18,37,38]$.

Previous studies have demonstrated that fiber diameter, pore size and porosity of scaffolds influence cell behavior such as proliferation, attachment and differentiation [39-41]. To better understand the effect of nanosurface roughness on hMSCs differentiation, the surface roughness was varied while keeping 


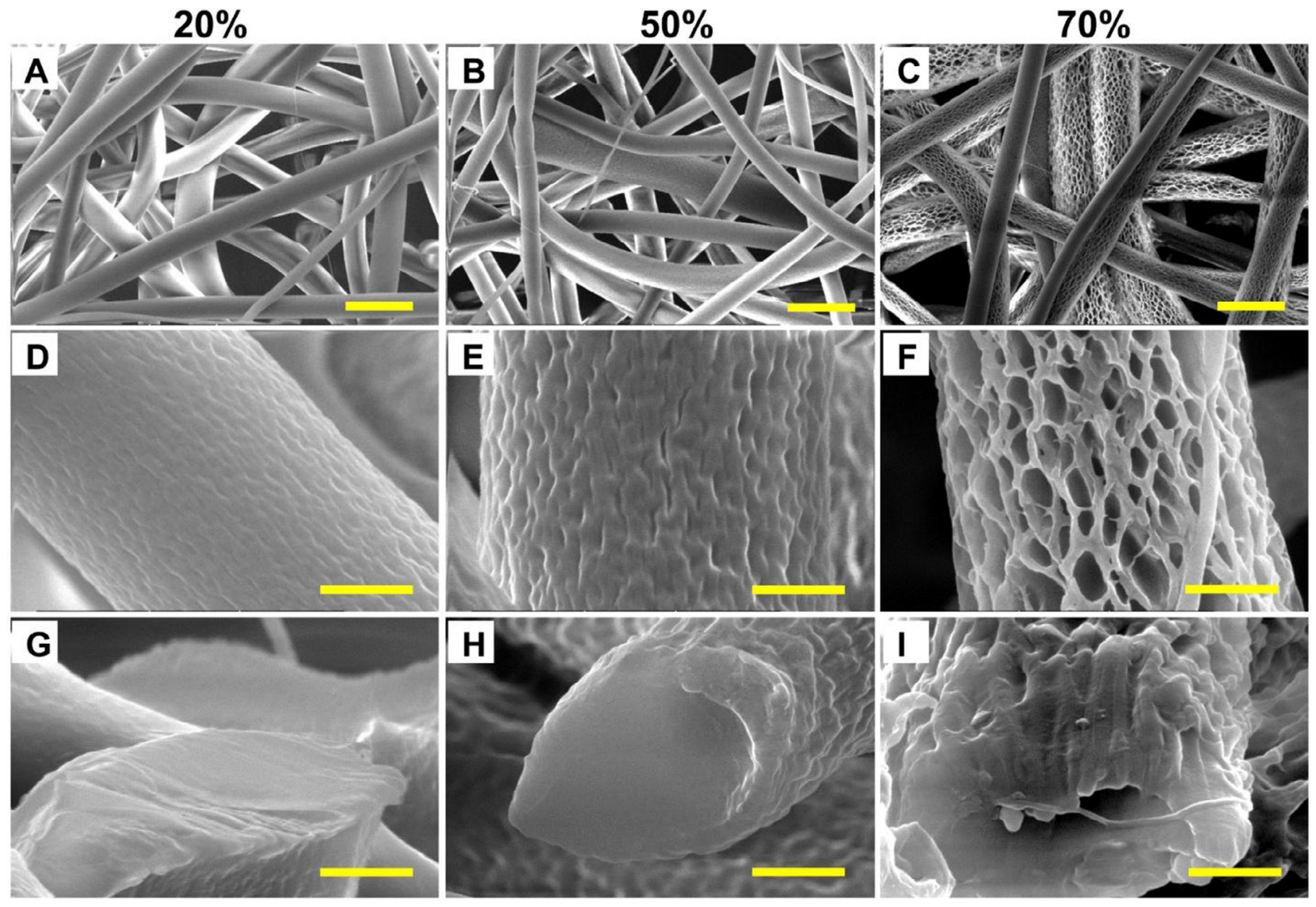

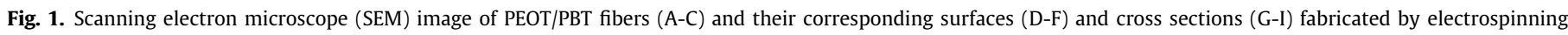
under different relative humidity: 20\% (A, D, G), 50\% (B, E, H) and 70\% (C, F,I). Scale bars are $10 \mu \mathrm{m}(\mathrm{A}-\mathrm{C})$ and $1 \mu \mathrm{m}(\mathrm{D}-\mathrm{I})$.

other structural parameters, such as fiber diameter, pore size and porosity of scaffolds constant. As shown in Fig. 3A and B, no significant differences in porosity and pore size of the electrospun scaffolds were found when changing the relative humidity. In addition, the obtained electrospun scaffolds had average fiber diameters of $3.8 \pm 0.8,3.5 \pm 1.0$, and $4.0 \pm 1.2 \mu \mathrm{m}$ for spinning from
A

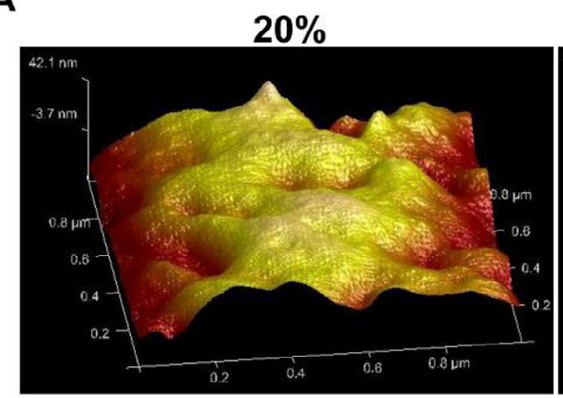

B

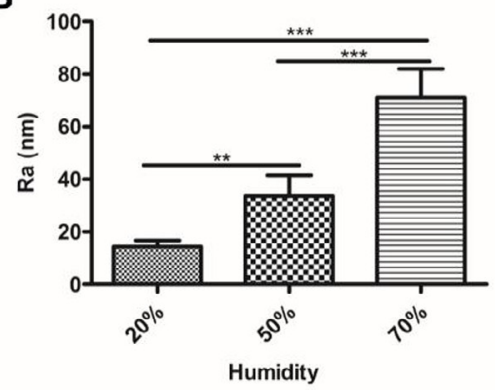

$50 \%$

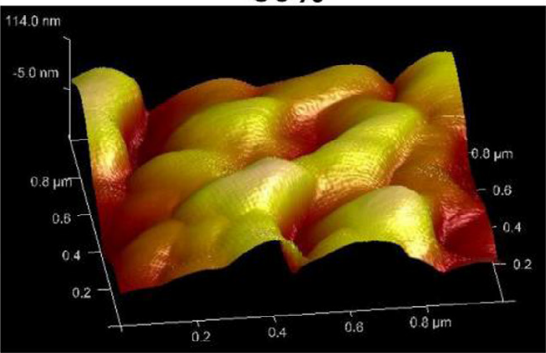

C

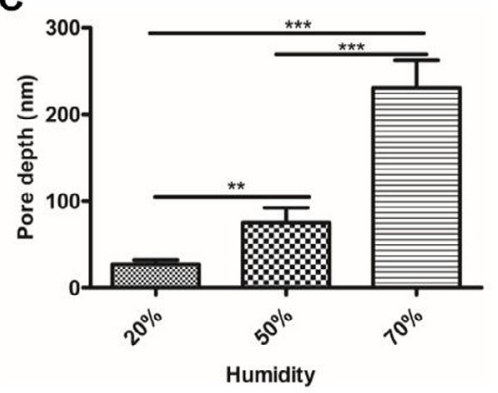

$70 \%$

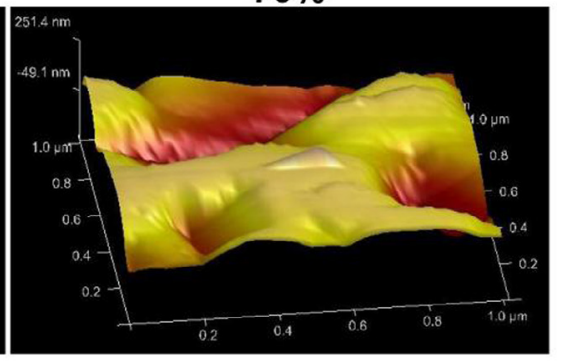

D

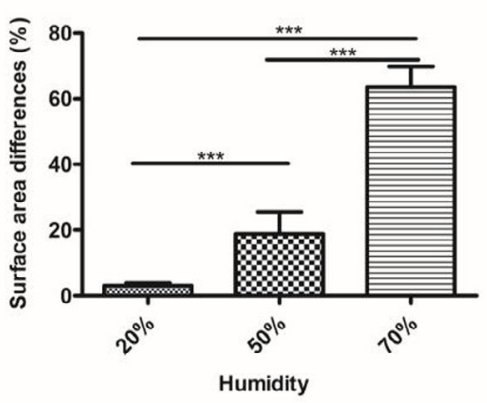

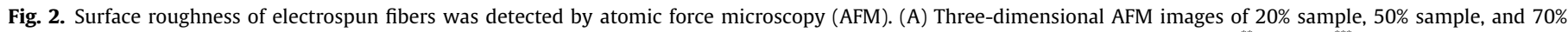
sample. (B) Graphs of average surface roughness (Ra) of scaffolds. (C) Pore depth of scaffolds. (D) Surface area differences of scaffolds. ${ }^{* *} \mathrm{p}<0.01$, ${ }^{* * * *} \mathrm{p}<0.001$. 
A

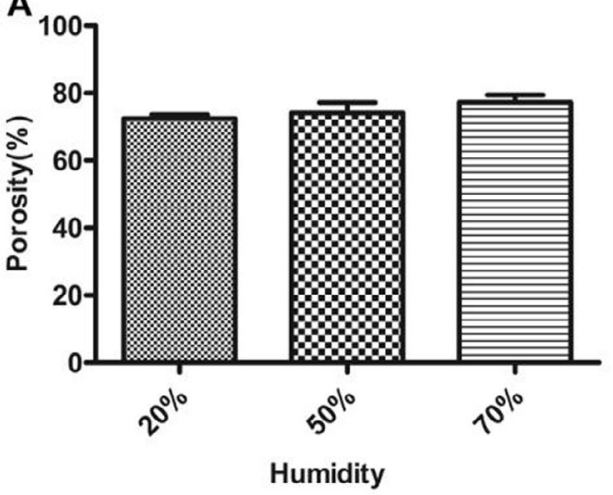

C

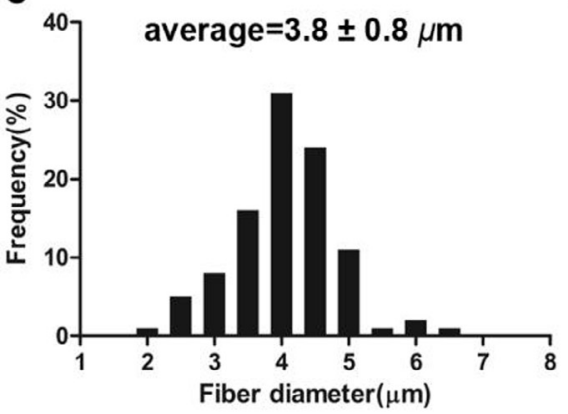

D

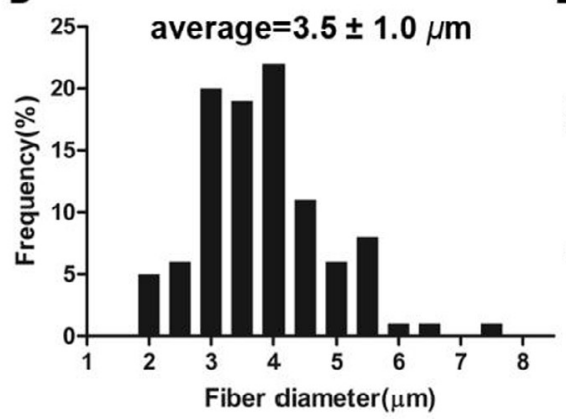

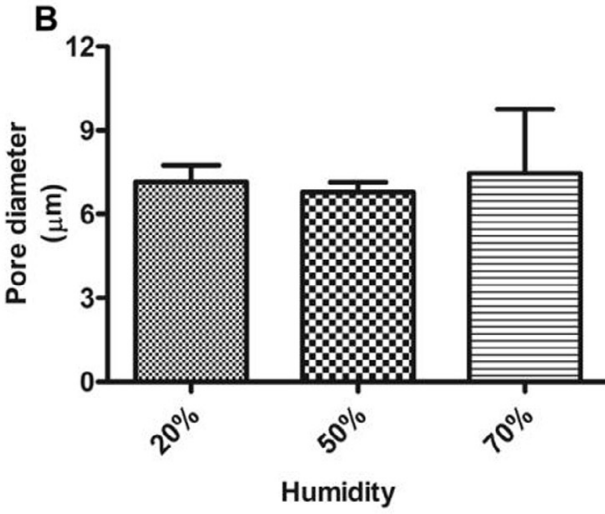

E

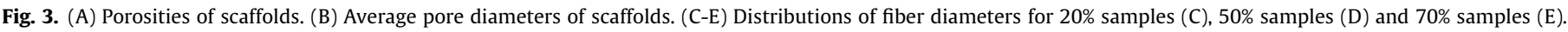

relative humidity of $20 \%, 50 \%$ and $70 \%$, respectively (Fig. 3C-E). The relative humidity is known to have an impact on fiber dimension which is essentially dependent on the polymer concentration as well as solvent used [38]. Given the fiber dimension scale range achieved in the present study, increasing relative humidity did not cause apparent difference in fiber dimension.

Chemical functional groups and/or blocks of the polymer chains may be reoriented during electrospinning process [42]. To determine the influence of relative humidity on the surface polarity of electrospun fibers, a Nile Red assay was employed (Fig. 4). Nile Red is a hydrophobic and solvatochromic dye [43] that has previously been used to determine the hydrophilicity/phobicity of a wide range of polymers in the bulk [44] and the variability of polymer surface environments [45]. Shifts in the absorption or emission maximum of the dye adsorbed to a polymer indicate differences in hydrophilicity/phobicity (dielectric strength). The electrospun fibers were stained with Nile Red homogeneously (Fig. 4A). As shown in Fig. 4B, for all electrospun scaffolds (20\%, $50 \%$, and $70 \%$ ), we found nearly identical emission intensity profiles (emission $\lambda_{\max }=600 \mathrm{~nm}$ ); this was in contrast to control samples, where we observed shifts in the emission intensity based on polymer composition. The identical emission profile of Nile Red across all our samples suggested that the electrospun scaffolds had similar polarity on their surface. To confirm these measurements, control samples of spin-cast poly (methyl methacrylate) (PMMA) and polycaprolactone (PCL) were shown to have distinctly different Nile Red emission profiles (Fig. S1). The PMMA had a lower emission profiles compared to PCL, which supported the fact that PMMA was more hydrophobic than PCL [44].

Surface wettability of scaffolds plays an important role in cell attachment and migration [46]. Wettability was assessed using contact angle measurements (Fig. 5A and B). Generally, water
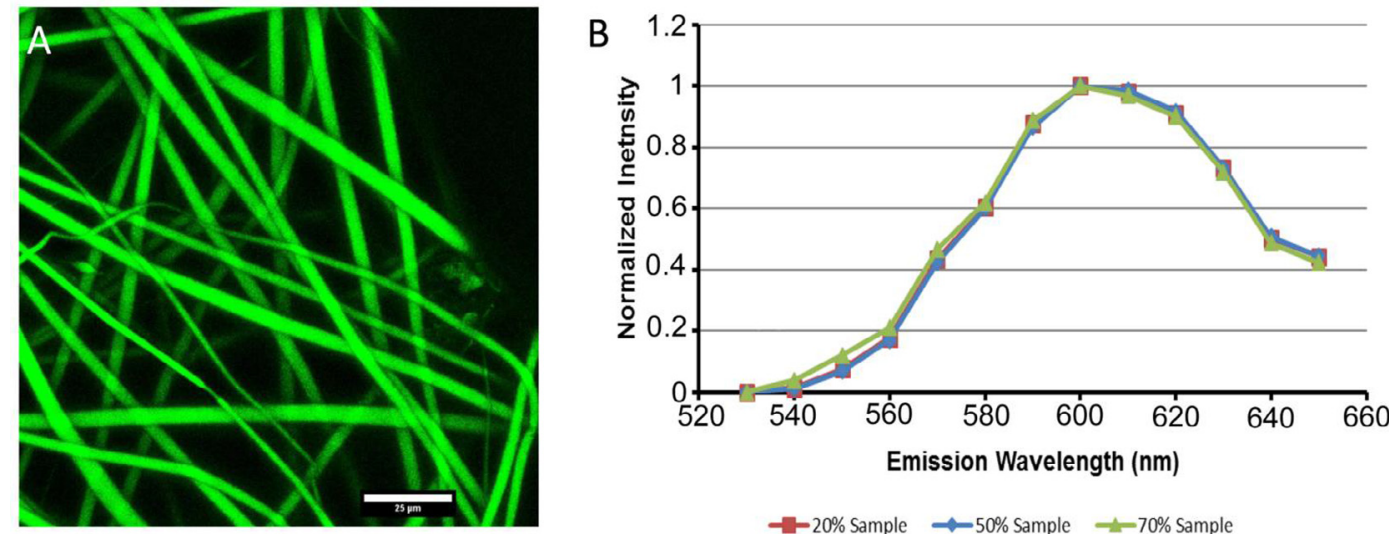

$-20 \%$ Sample $\rightarrow 50 \%$ Sample $\rightarrow-70 \%$ Sample

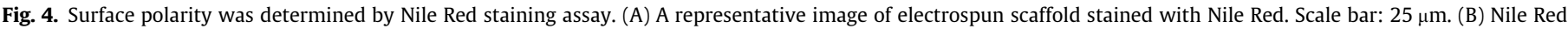
emission profiles of electrospun samples. Note that the samples have overlapping emission intensity profiles. $\lambda_{\mathrm{ex}}=514 \mathrm{~nm}$. 
sessile droplets penetrated into all scaffolds in the end, indicating hydrophilic properties of the mesh surface, probably due to the same chemical composition of scaffolds. In the present study, the material used for scaffold fabrication was PEOT/PBT which had a medium surface energy with an average contact angle of $48 \pm 1^{\circ}$ [47]. Although water droplets would ultimately penetrate into all scaffolds, their spreading speeds were different showing an inverse relationship with the surface roughness of scaffolds. Surface roughness, fiber diameter, and pore size are important factors affecting the contact angle of a surface, where the material itself is not varied [48]. As shown above, the scaffolds fabricated in different relative humidity displayed similar fiber dimension, pore size and surface chemistry, but varied surface roughness. Therefore, in the present study, the differences in surface energy were mainly attributed to their surface roughness. These findings are consistent with the results reported by Chuah et al., who demonstrated that increasing the surface roughness of polydimethylsiloxane (PDMS) substrates could enhance the hydrophobicity [49].

\subsection{Protein adsorption}

Protein adsorption on different scaffolds was examined using BSA as a model protein, and the results were shown after normalizing to the value of $20 \%$ sample. As shown in Fig. 6 , no significant difference in protein adsorption was observed between scaffolds from a relative humidity of $20 \%$ and $50 \%$, which could be attributed to their closed surface structure. On the other hand, scaffolds from a relative humidity of $70 \%$ showed significantly higher protein adsorption than scaffolds from a relative humidity of $20 \%$.This could be related to the increased surface roughness and surface porosity leading to a higher surface area. Such increased protein absorption was also shown by Nandakumar et al. [23] who used gas plasma for surface modification of electrospun fibers. A higher protein adsorption on scaffolds is also known to influence the cellular response such as cell adhesion, proliferation and differentiation $[50,51]$.

\subsection{Cell morphology and metabolic activity}

Cell morphology of hMSCs seeded on scaffolds characterized by different surface roughness was assessed by staining with phalloidin for actin filaments (Fig. 7). hMSCs on smoother surfaces (20\% and 50\% samples) tended to adopt an elongated and multipolar morphology, unlike hMSCs on rougher surfaces (70\% sample), which adopted smaller spindle shape.

Cell metabolic activity, which is indirectly associated with cell viability, was investigated by PrestoBlue ${ }^{\mathrm{TM}}$ assay (Fig. S2). The metabolic activity rate in BM at day 7 was similar to that of day

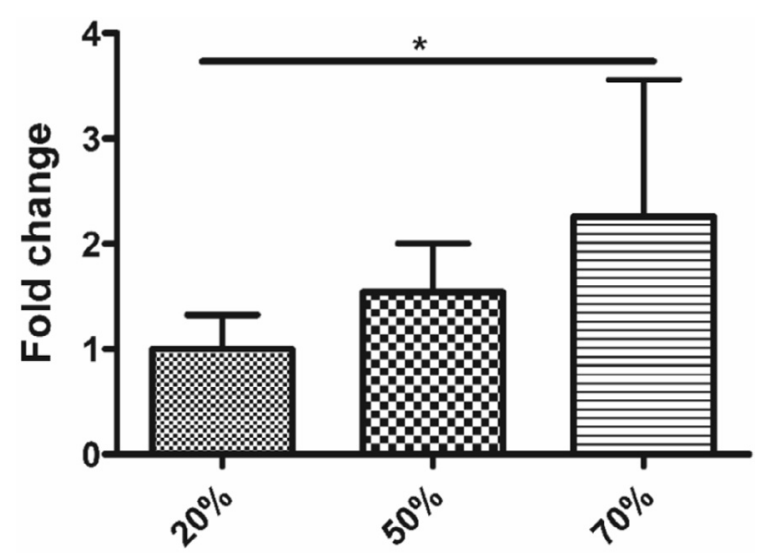

Fig. 6. The effect of surface roughness on protein adsorption. Bovine serum albumin (BSA) was used as model protein.

21, while a slightly lower metabolic activity was measured in $\mathrm{OM}$ and $\mathrm{CM}$ after 21 days. The decrease in metabolic activity rate in OM and CM could be ascribed to the differentiation of hMSCs. No statistical differences in metabolic activity were observed between the different surface roughness of scaffolds in all media investigated in this study.

\subsection{ALP activity and GAG production}

ALP activity, a common marker for early osteogenesis, is known to be up-regulated in the early stages of osteogenic differentiation [52]. As shown in Fig. 8A-B and Fig. S3, at day 7 a similar ALP activity in all kind of scaffolds was found in both BM and OM. In contrast, fibers (70\% sample) with a surface roughness of $71.0 \pm 11.0 \mathrm{~nm}$ displayed a higher ALP activity compared to fibers (20\% sample) with a roughness of $14.3 \pm 2.5 \mathrm{~nm}$ in BM at day 21 . A similar trend was also observed in OM. Therefore, it could be inferred that a higher surface roughness caused a higher ALP activity in the range studied in the present work. Our results were consistent with previous studies [53,54], where osteoblasts were demonstrated to have a higher ALP activity on a rougher surface of titanium substrates. Furthermore, our previous study has also demonstrated that hMSCs express evidently higher ALP activity on ceramic nanofibers displaying a rougher surface $(0.7 \pm 0.2 \mathrm{~nm})$ compared to a smoother one $(0.4 \pm 0.1 \mathrm{~nm})$ under osteogenic culture conditions [55].

GAG is a long-chain sugar molecule and plays an essential role in chondrogenic differentiation, since it is one of the main
A

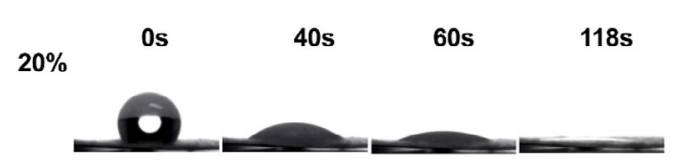

$50 \%$

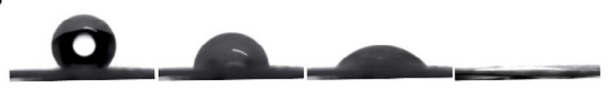

$70 \%$

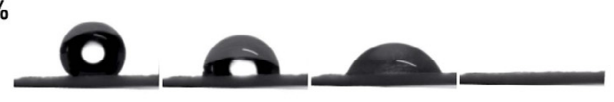

B

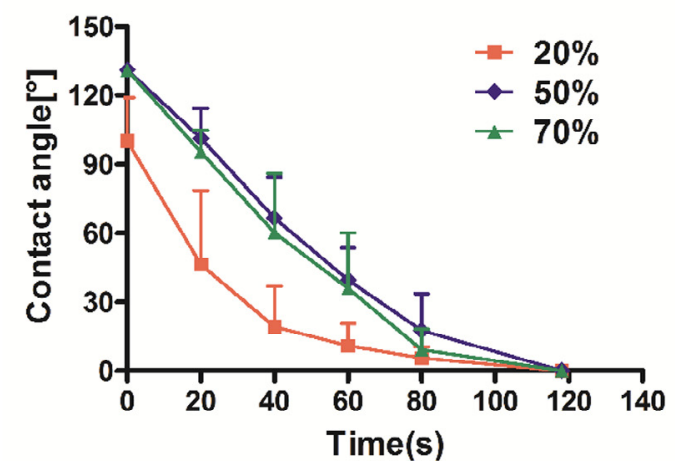

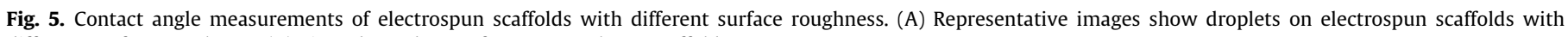
different surface roughness. (B) Time-dependency of contact angle on scaffolds. 

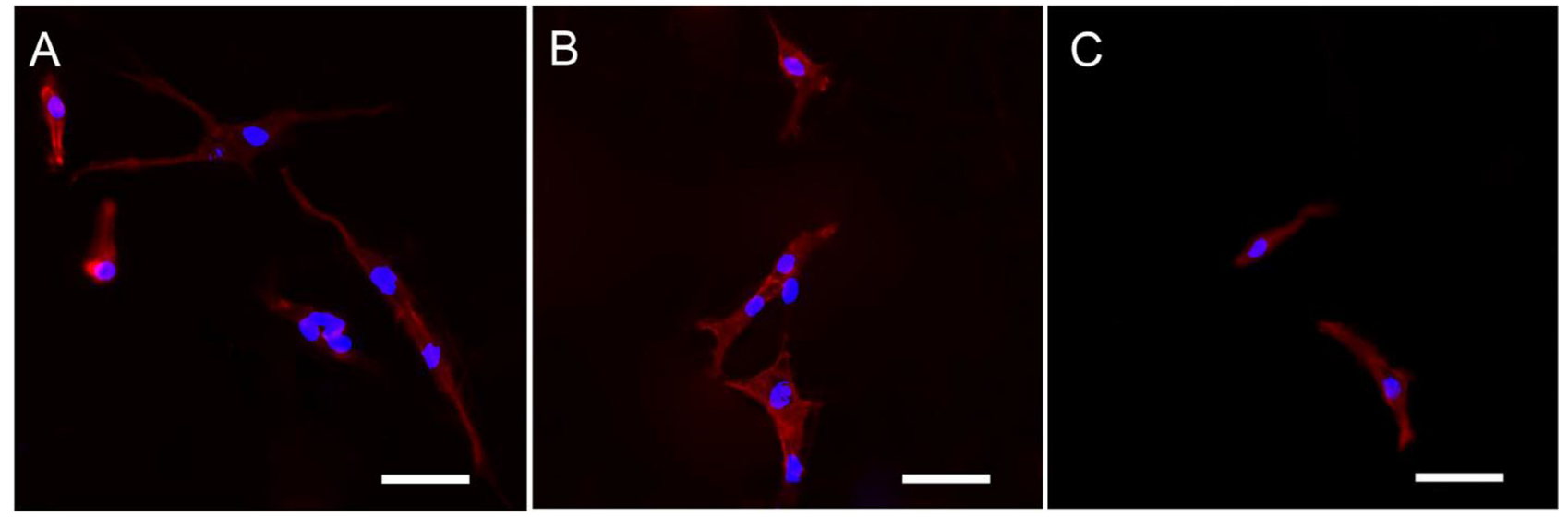

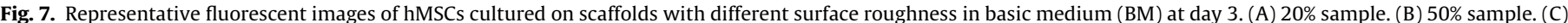

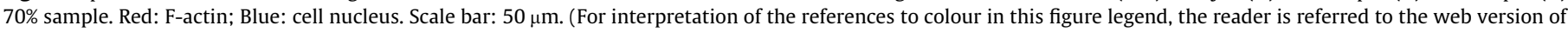
this article.)

A

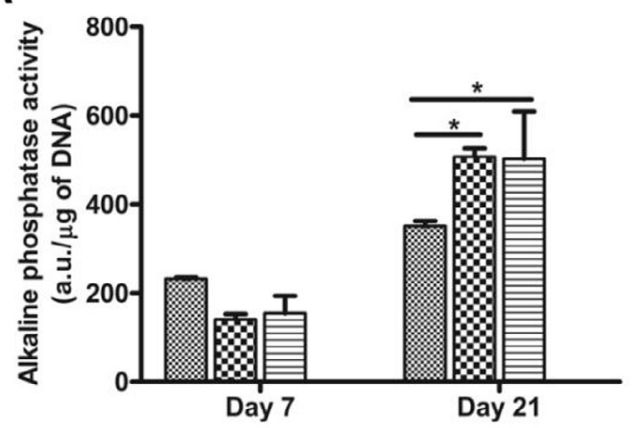

C

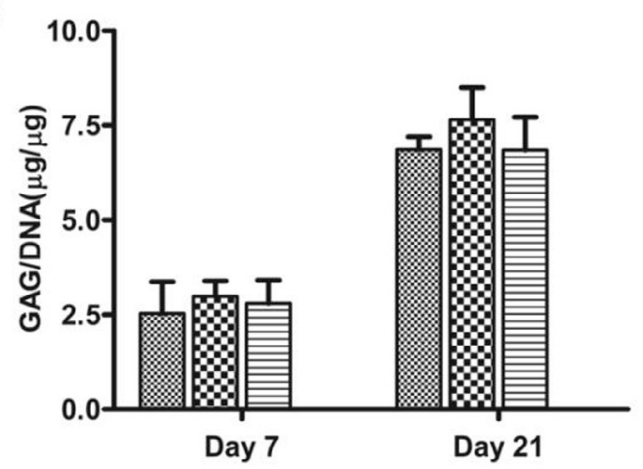

B
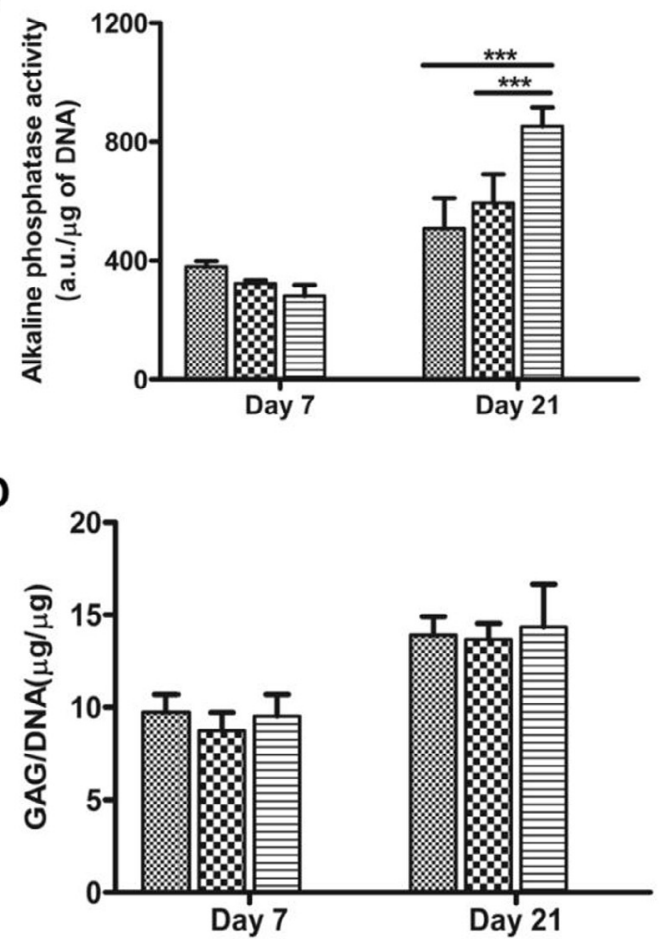

$50 \%$

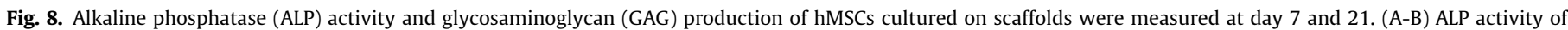

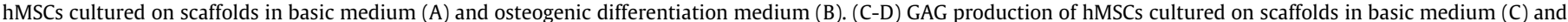
chondrogenic differentiation medium (D). The final results of ALP activity and GAG production levels were normalized by DNA amount. ${ }^{*}<0.05$, ${ }^{* * *} \mathrm{p}<0.001$.

components of the proteoglycans forming articular cartilage extracellular matrix [56]. In a previous study by our group, additive manufactured three-dimensional (3D) scaffolds whose polymer fibers had tailored surface roughness (ranging from $0.07 \pm 0.01$ $\mu \mathrm{m}$ to $1.95 \pm 0.55 \mu \mathrm{m}$ ) were fabricated in combination with a wet-spinning technique [57]. The results demonstrated that hMSCs on the highest roughness scaffolds $(1.95 \pm 0.55 \mu \mathrm{m})$ showed a higher GAG production under chondrogenic culture conditions. Despite the GAG production in all types of scaffolds enhanced over the experimental time course in all media (Fig. 8C-D and Fig. S4), no statistical difference in GAG production was found between the different surface roughness, indicating that the surface roughness nanometric range investigated in this study did not significantly influence GAG production by hMSCs during differentiation into the chondrogenic lineage.

\subsection{Osteogenic gene expression}

The influence of surface roughness on osteogenic differentiation was confirmed by real time RT-PCR (Fig. 9). To investigate osteoinductive and osteoconductive properties of different nanosurface roughness, hMSCs grown on scaffolds were treated with BM and 
$\mathrm{OM}$, respectively. BM is a maintenance medium that does not trigger the osteogenic differentiation of hMSCs, whereas OM induces osteogenic differentiation of hMSCs [58]. At day 7 in BM, some osteogenic genes, including OPN and BMP2 were significantly regulated for rougher fibers ( $70 \%$ sample) compared to smoother fibers (20\% sample), while other genes, such as bone sialoprotein (BSP), collagen type I (COL1A1) and osteocalcin (OCN) showed an opposite trend. In OM, RUNX2 expression was significantly higher on rougher fibers (70\% sample) compared to smoother fibers $(20 \%$ sample) at day 7. Conversely, BSP expression on smoother fibers
(20\% sample) was significantly higher than that on rougher fibers (70\% sample) after day 21.

Recent studies revealed that the hierarchical combination of micro- and nanoscale surface features promoted osteogenic differentiation $[59,60]$. Khang et al. reported that a stronger osteogenic differentiation of hMSCs was supported by a heterogeneous composition of nano and submicron hybrid surface features compared to only nano scale or sub-nano scale features [59]. In another study, Gittens et al. demonstrated that a combination of micro/ sub-micro scale surface roughness with nanoscale structures on
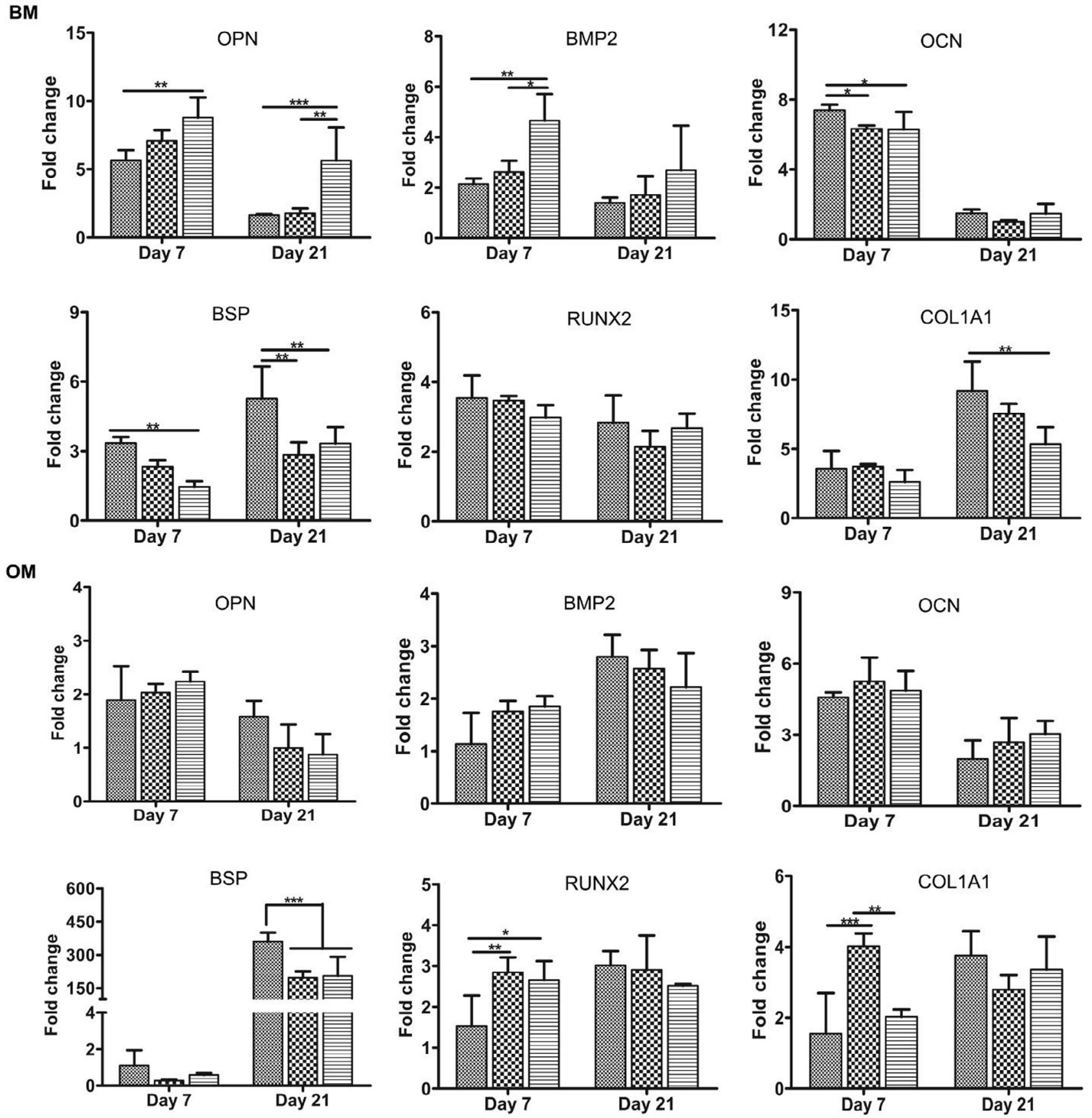
SOX9

$\mathrm{BM}$

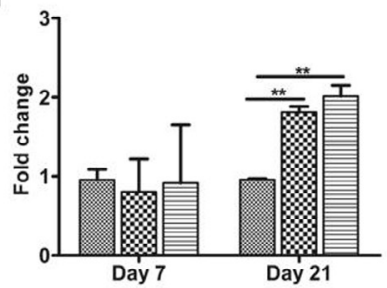

COL2A1

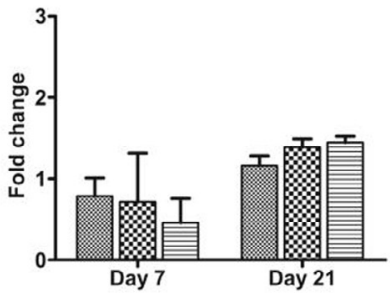

ALCAM

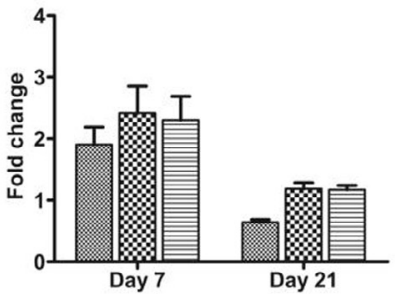

ACAN
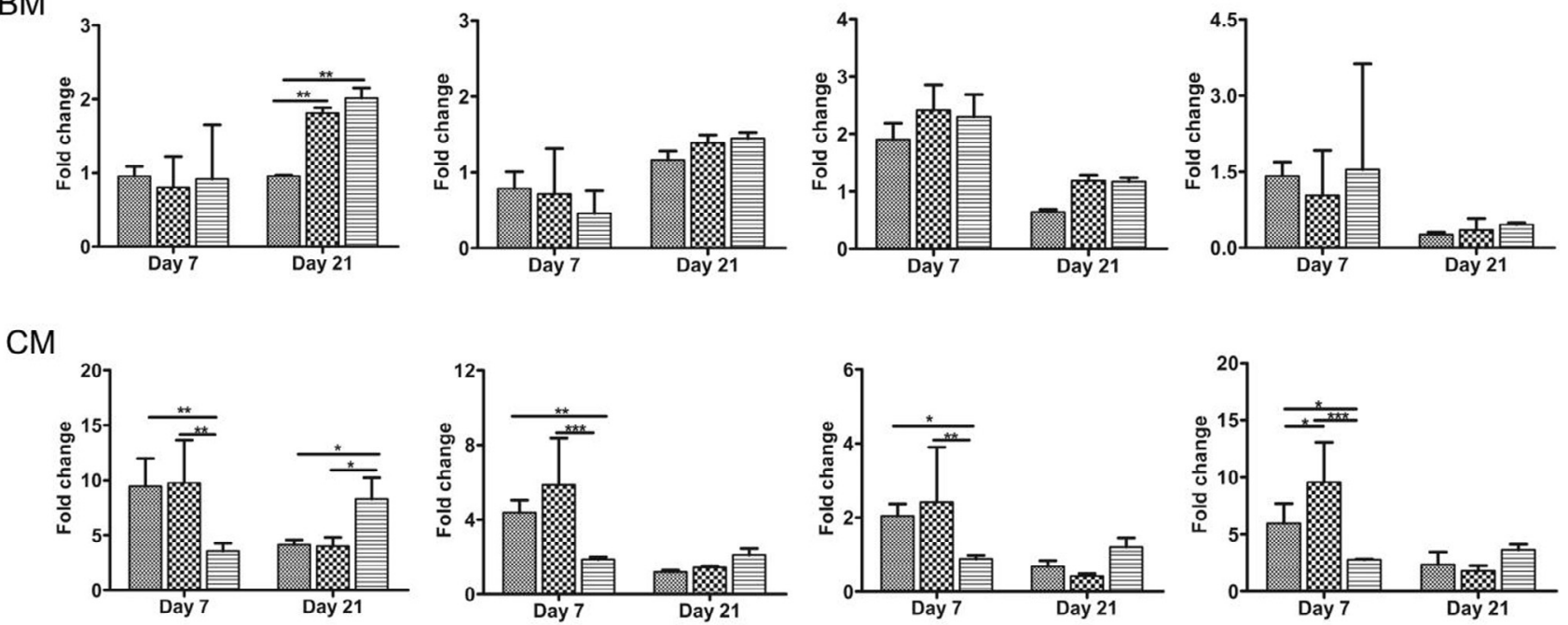

$\approx 20 \%$

E0 $50 \%$

$70 \%$

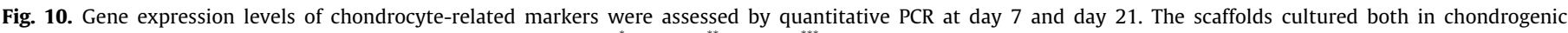
differentiation medium (CM) and basic medium (BM) were tested. ${ }^{*} \mathrm{p}<0.05,{ }^{* *} \mathrm{p}<0.01,{ }^{* * *} \mathrm{p}<0.001$.

Titanium surfaces enhanced osteoblast differentiation [60]. Therefore, it could be assumed that the hierarchical combination of different surface nanoroughness in electrospun fibers may be more beneficial on the osteogenic differentiation of hMSCs. Different gene expression profiles were observed between BM and OM. The differences could be dependent on the dominant stimuli during the process of osteogenic differentiation. In the present work, the osteogenic differentiation of hMSCs was mainly triggered by physical cues (such as surface roughness) and chemical stimuli (BM or OM). In BM, the morphologically (surface associated) driven properties, such as surface area and porosity, fibrous feature, and surface roughness, played important roles in triggering an initial osteogenic response. On the other hand, the chemical stimuli combined with physical cues played dominant roles in regulating osteogenesis in OM.

\subsection{Chondrogenic gene expression}

A panel of chondrocyte-related genes, including collagen type II alpha 1 (COL2A1), activated leukocyte cell adhesion molecule (ALCAM), SOX9, and aggrecan (ACAN) was investigated to assess hMSCs chondrogenesis (Fig. 10). In BM, only SOX9 was differentially regulated. On the other hand, the gene expression profiles were much different under chondrogenic differentiation culture conditions, most likely due to the dominant effect of chemical stimuli. In CM, upregulation of all tested chondrogenic markers was observed on both $20 \%$ and $50 \%$ samples compared to the $70 \%$ sample due to their different surface roughness. However, this trend was disappeared after 21 days. Recent work has suggested that the tendency of hMSCs differentiation which is trigged by surface topography stimuli may be discontinued when the surface topography cues disappear [57,61]. This might have also happened in this study when hMSCs were fully confluent on scaffolds and started being embedded within the endogenous ECM. SOX9 is known as an early chondrogenic transcription factor which controls the expression of genes related to matrix secretion [62].
Upregulation of SOX9 could be activated in mouse stromal ST2 cells cultured in low oxygen tension (hypoxic environment) [63]. The expression of SOX9 was significantly higher on rougher fibers (70\% sample) than on smoother fibers (20\% sample) in both BM and CM after 21 days. This might be related to the higher spatial proximity of the hMSCs cultured in rougher scaffolds, which facilitated cells condensation resulting in hypoxic condition when cells were confluent on the scaffolds $[57,64]$.

\section{Conclusion}

In the present work, electrospun fibers with three types of surface nanotopographies were directly fabricated by varying relative humidity during electrospinning. These scaffolds had similar fiber dimension, porosity and pore size, and chemical composition of the surface, yet a different surface roughness on the fibers. SEM and AFM results demonstrated that higher relative humidity resulted in higher surface roughness, pore depth and surface area in the nanoscale range. In order to investigate the impact of surface nanotopography of individual fibers on cell differentiation, hMSCs were cultured on scaffolds for 21 days in OM and CM. We found that a higher surface roughness ( $\mathrm{Ra}=71.0 \pm 11.0 \mathrm{~nm}$ ) showed enhanced expression of osteogenic genes such as OPN, BMP2, and RUNX2, while a lower surface roughness ( $R a=14.3 \pm 2.5 \mathrm{~nm}$ ) demonstrated enhanced other osteogenic genes expression, including BSP, COL1A1 and OCN. Interestingly, a lower surface roughness $(\mathrm{Ra}=14.3 \pm 2.5 \mathrm{~nm}$ ) showed to better support the chondrogenic differentiation of hMSCs at day 7 compared to higher surface roughness $(\mathrm{Ra}=71.0 \pm 11.0 \mathrm{~nm})$. Our work opens new avenues for tailoring surface nanoroughness of electrospun scaffolds to control the cellular response of hMSCs in tissue engineering and regenerative medicine. It is worth stating here that some additional studies should be performed in the future, including investigating release and degradation profiles, looking at the influence of surface roughness on fiber mechanical properties, and differences in cell adhesion depending on nanoroughness. 


\section{Acknowledgements}

H.C. thanks the China Scholarship Council for financial support (Grant \# 2011614016).

\section{Appendix A. Supplementary data}

Supplementary data associated with this article can be found, in the online version, at http://dx.doi.org/10.1016/j.actbio.2017.07. 003.

\section{References}

[1] Y.R.V. Shih, C.N. Chen, S.W. Tsai, Y.J. Wang, O.K. Lee, Growth of mesenchymal stem cells on electrospun type I collagen nanofibers, Stem Cells 24 (11) (2006) 2391-2397.

[2] M.B. Mueller, R.S. Tuan, Functional characterization of hypertrophy in chondrogenesis of human mesenchymal stem cells, Arthritis Rheum. 58 (5) (2008) 1377-1388.

[3] K. Le Blanc, M. Pittenger, Mesenchymal stem cells: progress toward promise, Cytotherapy 7 (1) (2005) 36-45.

[4] M.F. Pittenger, A.M. Mackay, S.C. Beck, R.K. Jaiswal, R. Douglas, J.D. Mosca, M.A. Moorman, D.W. Simonetti, S. Craig, D.R. Marshak, Multilineage potential of adult human mesenchymal stem cells, Science 284 (5411) (1999) 143-147.

[5] K. Pelttari, E. Steck, W. Richter, The use of mesenchymal stem cells for chondrogenesis, Injury 39 (1) (2008) 58-65.

[6] M. Pumberger, T.H. Qazi, M.C. Ehrentraut, M. Textor, J. Kueper, G. StoltenburgDidinger, T. Winkler, P. von Roth, S. Reinke, C. Borselli, Synthetic niche to modulate regenerative potential of MSCs and enhance skeletal muscle regeneration, Biomaterials 99 (2016) 95-108.

[7] A.I. Caplan, D. Correa, The MSC: an injury drugstore, Cell Stem Cell 9 (1) (2011) $11-15$.

[8] A.B. Faia-Torres, S. Guimond-Lischer, M. Rottmar, M. Charnley, T. Goren, K. Maniura-Weber, N.D. Spencer, R.L. Reis, M. Textor, N.M. Neves, Differential regulation of osteogenic differentiation of stem cells on surface roughness gradients, Biomaterials 35 (33) (2014) 9023-9032.

[9] C.J. Bettinger, R. Langer, J.T. Borenstein, Engineering substrate topography at the micro-and nanoscale to control cell function, Angew. Chem. Int. Ed. 48 (30) (2009) 5406-5415.

[10] M.J. Dalby, N. Gadegaard, R. Tare, A. Andar, M.O. Riehle, P. Herzyk, C.D. Wilkinson, R.O. Oreffo, The control of human mesenchymal cell differentiation using nanoscale symmetry and disorder, Nat. Mater. 6 (12) (2007) 997-1003.

[11] C.L. Casper, J.S. Stephens, N.G. Tassi, D.B. Chase, J.F. Rabolt, Controlling surface morphology of electrospun polystyrene fibers: effect of humidity and molecular weight in the electrospinning process, Macromolecules 37 (2) (2004) 573-578.

[12] D. Li, Y. Xia, Electrospinning of nanofibers: reinventing the wheel?, Adv Mater. 16 (14) (2004) 1151-1170.

[13] H. Chen, X. Fan, J. Xia, P. Chen, X. Zhou, J. Huang, J. Yu, P. Gu, Electrospun chitosan-graft-poly ( $\varepsilon$-caprolactone)/poly ( $\varepsilon$-caprolactone) nanofibrous scaffolds for retinal tissue engineering, Int. J. Nanomed. 6 (2011) 453.

[14] H. Chen, J. Huang, J. Yu, S. Liu, P. Gu, Electrospun chitosan-graft-poly ( $\varepsilon-$ caprolactone)/poly ( $\varepsilon$-caprolactone) cationic nanofibrous mats as potential scaffolds for skin tissue engineering, Int. J. Biol. Macromol. 48 (1) (2011) 1319.

[15] A. Nandakumar, R. Truckenmüller, M. Ahmed, F. Damanik, D.R. Santos, N. Auffermann, J. de Boer, P. Habibovic, C. van Blitterswijk, L. Moroni, A fast process for imprinting micro and nano patterns on electrospun fiber meshes at physiological temperatures, Small 9 (20) (2013) 3405-3409.

[16] J. Lee, S.Y. Lee, J. Jang, Y.H. Jeong, D.-W. Cho, Fabrication of patterned nanofibrous mats using direct-write electrospinning, Langmuir 28 (18) (2012) 7267-7275.

[17] C.H. Kim, Y.H. Jung, H.Y. Kim, D.R. Lee, N. Dharmaraj, K.E. Choi, Effect of collector temperature on the porous structure of electrospun fibers, Macromol. Res. 14 (1) (2006) 59-65.

[18] P. Lu, Y. Xia, Maneuvering the internal porosity and surface morphology of electrospun polystyrene yarns by controlling the solvent and relative humidity, Langmuir 29 (23) (2013) 7070-7078.

[19] N. Sachot, O. Castaño, M.A. Mateos-Timoneda, E. Engel, J.A. Planell, Hierarchically engineered fibrous scaffolds for bone regeneration, J. R. Soc. Interface 10 (88) (2013) 20130684.

[20] N.D. Luong, I.-S. Moon, D.S. Lee, Y.-K. Lee, J.-D. Nam, Surface modification of poly (l-lactide) electrospun fibers with nanocrystal hydroxyapatite for engineered scaffold applications, Mater. Sci. Eng., C 28 (8) (2008) 1242-1249.

[21] J. Chen, B. Chu, B.S. Hsiao, Mineralization of hydroxyapatite in electrospun nanofibrous poly (L-lactic acid) scaffolds, J. Biomed. Mater. Res., Part A 79 (2) (2006) 307-317.

[22] Y. Zhang, J. Li, G. An, X. He, Highly porous $\mathrm{SnO}_{2}$ fibers by electrospinning and oxygen plasma etching and its ethanol-sensing properties, Sens. Actuators B: Chem. 144 (1) (2010) 43-48.
[23] A. Nandakumar, Z.T. Birgani, D. Santos, A. Mentink, N. Auffermann, K. van der Werf, M. Bennink, L. Moroni, C. van Blitterswijk, P. Habibovic, Surface modification of electrospun fibre meshes by oxygen plasma for bone regeneration, Biofabrication 5 (1) (2013) 015006.

[24] M.M. Demir, M.A. Gulgun, Y.Z. Menceloglu, B. Erman, S.S. Abramchuk, E.E Makhaeva, A.R. Khokhlov, V.G. Matveeva, M.G. Sulman, Palladium nanoparticles by electrospinning from poly (acrylonitrile-co-acrylic acid)$\mathrm{PdCl} 2$ solutions. Relations between preparation conditions, particle size, and catalytic activity, Macromolecules 37 (5) (2004) 1787-1792.

[25] A. Martins, E.D. Pinho, S. Faria, I. Pashkuleva, A.P. Marques, R.L. Reis, N.M Neves, Surface modification of electrospun polycaprolactone nanofiber meshes by plasma treatment to enhance biological performance, Small 5 (10) (2009) 1195-1206.

[26] L. Moroni, R. Licht, J. de Boer, J.R. de Wijn, C.A. van Blitterswijk, Fiber diameter and texture of electrospun PEOT/PBT scaffolds influence human mesenchymal stem cell proliferation and morphology, and the release of incorporated compounds, Biomaterials 27 (28) (2006) 4911-4922.

[27] F. Zamani, M. Amani-Tehran, M. Latifi, M.A. Shokrgozar, The influence of surface nanoroughness of electrospun PLGA nanofibrous scaffold on nerve cell adhesion and proliferation, J. Mater. Sci. - Mater. Med. 24 (6) (2013) 1551 1560.

[28] Q. Zhou, J. Xie, M. Bao, H. Yuan, Z. Ye, X. Lou, Y. Zhang, Engineering aligned electrospun PLLA microfibers with nano-porous surface nanotopography for modulating the responses of vascular smooth muscle cells, J. Mater. Chem. B 3 (21) (2015) 4439-4450.

[29] M.F. Leong, K.S. Chian, P.S. Mhaisalkar, W.F. Ong, B.D. Ratner, Effect of electrospun poly (D, L-lactide) fibrous scaffold with nanoporous surface on attachment of porcine esophageal epithelial cells and protein adsorption, J. Biomed. Mater. Res., Part A 89 (4) (2009) 1040-1048.

[30] S. Liao, L.T. Nguyen, M. Ngiam, C. Wang, Z. Cheng, C.K. Chan, S. Ramakrishna, Biomimetic nanocomposites to control osteogenic differentiation of human mesenchymal stem cells, Adv. Healthcare Mater. 3 (5) (2014) 737-751.

[31] J. Rnjak-Kovacina, S.G. Wise, Z. Li, P.K. Maitz, C.J. Young, Y. Wang, A.S. Weiss, Tailoring the porosity and pore size of electrospun synthetic human elastin scaffolds for dermal tissue engineering, Biomaterials 32 (28) (2011) 67296736.

[32] C.M. DiGirolamo, D. Stokes, D. Colter, D.G. Phinney, R. Class, D.J. Prockop, Propagation and senescence of human marrow stromal cells in culture: a simple colony-forming assay identifies samples with the greatest potential to propagate and differentiate, Br. J. Haematol. 107 (2) (1999) 275-281.

[33] A. Leferink, W. Hendrikson, J. Rouwkema, M. Karperien, V.C. Blitterswijk, L. Moroni. Increased cell seeding efficiency in bioplotted three-dimensional PEOT/PBT scaffolds. J. Tissue Eng. Regener. Med, 2013.

[34] A. Nandakumar, H. Fernandes, J. de Boer, L. Moroni, P. Habibovic, C.A. van Blitterswijk, Fabrication of bioactive composite scaffolds by electrospinning for bone regeneration, Macromol. Biosci. 10 (11) (2010) 1365-1373.

[35] P. Lu, Y. Xia, Maneuvering the internal porosity and surface morphology of electrospun polystyrene yarns by controlling the solvent and relative humidity, Langmuir 29 (23) (2013) 7070.

[36] M. Bognitzki, W. Czado, T. Frese, A. Schaper, M. Hellwig, M. Steinhart, A. Greiner, J.H. Wendorff, Nanostructured fibers via electrospinning, Adv. Mater. 13 (1) (2001) 70-72.

[37] S. Megelski, J.S. Stephens, D.B. Chase, J.F. Rabolt, Micro-and nanostructured surface morphology on electrospun polymer fibers, Macromolecules 35 (22) (2002) 8456-8466.

[38] G.-T. Kim, J.-S. Lee, J.-H. Shin, Y.-C. Ahn, Y.-J. Hwang, H.-S. Shin, J.-K. Lee, C.-M. Sung, Investigation of pore formation for polystyrene electrospun fiber: effect of relative humidity, Korean J. Chem. Eng. 22 (5) (2005) 783-788.

[39] J.L. Lowery, N. Datta, G.C. Rutledge, Effect of fiber diameter, pore size and seeding method on growth of human dermal fibroblasts in electrospun poly ( $\varepsilon$ caprolactone) fibrous mats, Biomaterials 31 (3) (2010) 491-504.

[40] P. Kasten, I. Beyen, P. Niemeyer, R. Luginbühl, M. Bohner, W. Richter, Porosity and pore size of $\beta$-tricalcium phosphate scaffold can influence protein production and osteogenic differentiation of human mesenchymal stem cells: an in vitro and in vivo study, Acta Biomater. 4 (6) (2008) 1904 1915.

[41] A.S. Badami, M.R. Kreke, M.S. Thompson, J.S. Riffle, A.S. Goldstein, Effect of fiber diameter on spreading, proliferation, and differentiation of osteoblastic cells on electrospun poly (lactic acid) substrates, Biomaterials 27 (4) (2006) 596606.

[42] U. Stachewicz, C.A. Stone, C.R. Willis, A.H. Barber, Charge assisted tailoring of chemical functionality at electrospun nanofiber surfaces, J. Mater. Chem. 22 (43) (2012) 22935-22941.

[43] A.K. Dutta, K. Kamada, K. Ohta, Spectroscopic studies of nile red in organic solvents and polymers, J. Photochem. Photobiol. A: Chem. 93 (1) (1996) 57-64.

[44] A.J. Magenau, J.A. Richards, M.A. Pasquinelli, D.A. Savin, R.T. Mathers, Systematic insights from medicinal chemistry to discern the nature of polymer hydrophobicity, Macromolecules 48 (19) (2015) 7230-7236.

[45] Y. Hou, A.M. Bardo, C. Martinez, D.A. Higgins, Characterization of molecular scale environments in polymer films by single molecule spectroscopy, J. Phys. Chem. B 104 (2) (2000) 212-219.

[46] L. Ghasemi-Mobarakeh, M.P. Prabhakaran, M. Morshed, M.-H. Nasr-Esfahani, S. Ramakrishna, Electrospun poly ( $\varepsilon$-caprolactone)/gelatin nanofibrous scaffolds for nerve tissue engineering, Biomaterials 29 (34) (2008) 4532-4539. 
[47] A.A. Deschamps, M.B. Claase, W.J. Sleijster, J.D. de Bruijn, D.W. Grijpma, J Feijen, Design of segmented poly (ether ester) materials and structures for the tissue engineering of bone, J. Controlled Release 78 (1) (2002) 175-186.

[48] I. Wimpenny, N. Ashammakhi, Y. Yang, Chondrogenic potential of electrospun nanofibres for cartilage tissue engineering, J. Tissue Eng. Regener. Med. 6 (7) (2012) 536-549.

[49] Y.J. Chuah, Y. Zhang, Y. Wu, N.V. Menon, G.H. Goh, A.C. Lee, V. Chan, Y. Zhang, Y. Kang, Combinatorial effect of substratum properties on mesenchymal sten cell sheet engineering and subsequent multi-lineage differentiation. Acta Biomater. 23 (2015) 52-62.

[50] G. Wei, P.X. Ma, Partially nanofibrous architecture of 3D tissue engineering scaffolds, Biomaterials 30 (32) (2009) 6426-6434.

[51] M.S. Lord, M. Foss, F. Besenbacher, Influence of nanoscale surface topography on protein adsorption and cellular response, Nano Today 5 (1) (2010) 66-78.

[52] A.K. Gaharwar, S.M. Mihaila, A. Swami, A. Patel, S. Sant, R.L. Reis, A.P. Marques, M.E. Gomes, A. Khademhosseini, Bioactive silicate nanoplatelets for osteogenic differentiation of human mesenchymal stem cells, Adv. Mater. 25 (24) (2013) 3329-3336.

[53] Y. Wu, J.P. Zitelli, K.S. TenHuisen, X. Yu, M.R. Libera, Differential response of Staphylococci and osteoblasts to varying titanium surface roughness, Biomaterials 32 (4) (2011) 951-960.

[54] M.-J. Kim, M.-U. Choi, C.-W. Kim, Activation of phospholipase D1 by surface roughness of titanium in MG63 osteoblast-like cell, Biomaterials 27 (32) (2006) 5502-5511.

[55] G. Cadafalch Gazquez, H. Chen, S.A. Veldhuis, A. Solmaz, C. Mota, B.A Boukamp, C.A. van Blitterswijk, J.E. ten Elshof, L. Moroni, Flexible YttriumStabilized Zirconia Nanofibers Offer Bioactive Cues for Osteogenic Differentiation of Human Mesenchymal Stromal Cells, ACS Nano, 2016.

[56] B.C. Heng, T. Cao, E.H. Lee, Directing stem cell differentiation into the chondrogenic lineage in vitro, Stem Cells 22 (7) (2004) 1152-1167.

[57] S.C. Neves, C. Mota, A. Longoni, C.C. Barrias, P.L. Granja, L. Moroni, Additive manufactured polymeric 3D scaffolds with tailored surface topography influence mesenchymal stromal cells activity, Biofabrication 8 (2) (2016) 025012.

[58] G. Cadafalch Gazquez, H. Chen, S.A. Veldhuis, A. Solmaz, C. Mota, B.A. Boukamp, C.A. van Blitterswijk, J.E. ten Elshof, L. Moroni, Flexible yttriumstabilized zirconia nanofibers offer bioactive cues for osteogenic differentiation of human mesenchymal stromal cells, ACS Nano 10 (6) (2016) 5789-5799.

[59] D. Khang, J. Choi, Y.-M. Im, Y.-J. Kim, J.-H. Jang, S.S. Kang, T.-H. Nam, J. Song, J.W. Park, Role of subnano-, nano-and submicron-surface features on osteoblast differentiation of bone marrow mesenchymal stem cells, Biomaterials 33 (26) (2012) 5997-6007.

[60] R.A. Gittens, T. McLachlan, R. Olivares-Navarrete, Y. Cai, S. Berner, R. Tannenbaum, Z. Schwartz, K.H. Sandhage, B.D. Boyan, The effects of combined micron-/submicron-scale surface roughness and nanoscale features on cell proliferation and differentiation, Biomaterials 32 (13) (2011) 3395-3403.

[61] G. Abagnale, M. Steger, V.H. Nguyen, N. Hersch, A. Sechi, S. Joussen, B. Denecke, R. Merkel, B. Hoffmann, A. Dreser, Surface topography enhances differentiation of mesenchymal stem cells towards osteogenic and adipogenic lineages, Biomaterials 61 (2015) 316-326.

[62] R. Takács, C. Matta, C. Somogyi, T. Juhász, R. Zákány, Comparative analysis of osteogenic/chondrogenic differentiation potential in primary limb budderived and C3H10T1/2 cell line-based mouse micromass cultures, Int. J. Mol. Sci. 14 (8) (2013) 16141-16167.

[63] J.C. Robins, N. Akeno, A. Mukherjee, R.R. Dalal, B.J. Aronow, P. Koopman, T.L. Clemens, Hypoxia induces chondrocyte-specific gene expression in mesenchymal cells in association with transcriptional activation of Sox9, Bone 37 (3) (2005) 313-322.

[64] Q. Zhao, H. Eberspaecher, V. Lefebvre, B. De Crombrugghe, Parallel expression of Sox9 and Col2a1 in cells undergoing chondrogenesis, Dev. Dyn. 209 (4) (1997) 377-386. 